\title{
МЕТОД ЛІ СТРАСБЕРГА ЯК ЕВОЛЮЦІЙНИЙ РОЗВИТОК СИСТЕМИ К. С. СТАНІСЛАВСЬКОГО
}

У статті розглядається метод Лі Страсберга як новітня сучасна система фахової підготовки актора. Надається перелік вправ, які рекомендується виконувати у незмінній послідовності для удосконалення елементів техніки актора.

Ключові слова: театральне мистецтво, система, метод, афективна пам'ять.

В статье рассматривается метод Ли Страсберга как новейшая современная система профессианальной подготовки актера. Прилагается перечень упражнений, которые рекомендуется выполнять в строгой последовательности для усовершенствования элементов техники актера.

Ключевые слова: театральное искусство, система, метод, аффективная память.

The article reveals the Lee Strasberg method as the newest modern system of vocational training. A list of exercises is attached, some are recommended to be performed in strict sequence to improve the elements of the actor's technique.

Key words: theater art, system, method, affective memory.

Мета праці полягає у виявленні й теоретичному обгрунтуванні умов створення методу Лі Страсберга як еволюційного продовження системи Станіславського, який сприяє ефективному оволодінню акторською технікою. Здійснено спробу систематизувати відкриття Лі Страсберга та створити модель навчання для виховання актора Методу у навчальних закладах України.

Методологія дослідження полягає у використанні сукупності загальнонаукових та спеціальних методів, а саме: аналітичного, порівняльного аналізу, функціонального, діахронічного.

Наукова новизна праці полягає у спробі дослідити метод Лі Страсберга, як удосконалення методики викладання акторської майстерності в Україні.

Висновки: творче наслідування К. С. Станіславського і театральна педагогіка Лі Страсберга різні у підходах до досягнення творчого самопочуття, але єдині у головному - у пошуках об'єктивних законів акторського мистецтва. Саме тому ця стаття підтверджує цінність американської гілки розвитку системи К. С. Станіславського, а також наголошує на запозиченні цілого ряду положень методології Лі Страсберга для удосконалення сучасної театральної педагогіки. $€$ доцільним не протиставляти Систему і Метод, не розділяти школи, які спираються на наслідування Станіславського, на російську і американську, а виявляти і наголошувати їх спільність і можливість взаємодії. Методологія акторської творчості, пошук об'єктивних законів природи у творчості актора не можуть бути обмежені національними рамками.

Аналіз положень раннього періоду системи Станіславського потребує, насамперед, тлумачення словосполучення «система Станіславського». У варіанті передмови до книги «Робота актора над собою», котра не була опублікована у 30 -ті роки XX ст., Костянтин Сергійович пише: «Нехай артисти і сценічні діячі творять що і як їм заманеться, але за однієї необхідної умови: щоб їх творчість не йшла урозріз із самою природою і ії законами. Для того щоб співати комуністичний "Інтернаціонал” або царський гімн, необхідно мати поставлений голос і техніку. Ось про цю постановку і техніку в сфері нашого мистецтва лише виключно і свідчить ця книга. Вона написана на захист законів природи» [5].

Саме цю позицію в основу свого методу і взяв Лі Страсберг, тому у цій праці під терміном «система Станіславського» буде використовуватись не усе наслідування системи, а лише його части- 
на - система професійного навчання і виховання актора, побудована на вивченні об'єктивних законів природи.

У рукописі під назвою «Виховання правильного самопочуття» Станіславський наводить такий список окремих елементів творчого самопочуття актора:

Ослаблення м'язового напруження;

Афективні переживання;

Афективна пам'ять;

Зосередженість почуття, або творча зосередженість, або коло зосередженості (далі Станіславський буде використовувати коло уваги);

Спілкування;

Думка і слово, наш виразник і протокол почуттів;

Розчленування і аналіз почуттів і думки (даліуривки і завдання);

Словесна передача почуттів (далі - словесна дія);

Пристосування до характеру співрозмовника у передачі образних ілюстрацій (далі — пристосування і бачення);

Пристосування заради бажання відчути чужі почуття (далі - сприйняття і вплив);

Розвиток творчої звички (далі — тренінг і муштра);

І т. д. [2].

Такий перелік елементів ставить питання про пріоритетність елементів у розвитку артиста. Звісно, у різний час дослідницької діяльності К. Станіславського пріоритетність була різною, саме це і формує межі періодів його творчого життя, але у перший період його досліджень у пріоритеті був такий елемент, як афективна пам'ять. На відміну від інших видів пам'яті (слухової, зорової та інших), афективна пам'ять запам'ятовує не самі факти і обстановку, а саме фізичні почуття і душевні відчуття, котрі їх супроводжують [3].

К. С. Станіславський всіляко наполягає, що актор у ролі може і навіть повинен жити лише власними почуттями, а не чужими. Потрібний матеріал для створення сценічного образу треба весь час шукати у власному житті, звертатись до власного досвіду, знаходити в ньому схожі відчуття, аналогічні з переживаннями його персонажа. Саме афективна пам'ять може викликати у актора потрібні за ходом дії п'єси переживання, які він переживав колись у відповідних обставинах його власного життя. Цитуючи Г. В. Крісті, можна наголосити принциповість такої його позиції: «Станіславський завжди вважав життєвий досвід актора ширшим і цікавішим за його акторський досвід. Тому слідом за Щепкіним він вимагав від актора в роботі над роллю “йти від життя”, а не від звичних умовностей сцени...» [1].

Неможливо не звернути увагу, що у цей період своєї творчості режисер вивчав основні закони йоги, які надали нового тлумачення вже відомим елементам, а також збагатили Систему положеннями, котрраніше в ній не було.

Саме йога подарувала К. С. Станіславському концептуальну ідею зв'язку творчого стану і несвідомого, в ній він запозичив уявлення про надсвідомість як джерело творчої інтуїції та трансцендентального знання. Несвідоме життя людини, для К. Станіславського, складається 3 двох складових - підсвідомість, яка є у кожного індивідуума, та надсвідомість, яка перевершує індивідуума, так би мовити, вища свідомість, сфера трансцендентного. Мистецтво торкається саме цієї Вищої складової, відкриваючи іï, і саме тому може говорити над культурами і століттями [6].

Сам Станіславський ніколи не давав чіткого визначення, що таке надсвідомість і підсвідомість. Застосовуючи два таких схожих терміна, як «підсвідомість» та «понадсвідомість», слід розуміти, що Станіславський незважаючи на синонімічні слова, виявляє надзвичайно глибоку і вагому різницю двох механізмів, котрі беруть участь у творчому акті. Підсвідомість керує суто індивідуальними пристосувальними реакціями організму, автоматизованими навичками, відтінками емоцій і їх зовнішнім виразом; у свою чергу надсвідомість бере участь «у формуванні гіпотез, пізнавальних мотивацій» i «осягає ті сфери дійсності, прагматична цінність яких сумнівна, незрозуміла» $[7,5]$. Понадсвідомість відкриває невідоме, свідомість підкидає штамп. Взаємопов'язане розроблення трьох проаналізованих аспектів Системи (використання афективної пам'яті, йогівські принципи у тренінгах елементів творчого самопочуття, а також виникнення концепції понадсвідомості) були основою роботи Станіславського протягом всієї першої половини 1910-х років.

Так званий «ранній період» Системи, який стане основою для методу Лі Страсберга, починався досить принциповим формулюванням необхідності пошуків об' єктивних законів психофізіології у творчості актора, тоді ж був введений принцип системності у роботу актора над собою і над роллю.

До часу перших гастролей Художнього театру в Америці, які відбулись у 1923 році, американці вже були достатньо підготовлені і достатньо налаштовані на хвилю європейського мистецтва, у всіх його проявах. К. Станіславський про це сказав: «... американський глядач бачив усе краще, що є в Свропі» $[6,381]$. Однак гастролі російського театру 
назавжди змінили хід театральної історії Америки. Поїздка МХТ перетворилась у справжню «російську театральну революцію», яка ввергла Америку в шок. Усі критики писали про завоювання Америки російським театром: «Трупа Станіславського ніби громом вразила театральний світ Нью-Йорка, який ніколи не бачив нічого подібного за його постановки» $[9,31]$.

Поняття ансамблю, групи однодумців стало визначальним для усього американського досвіду освоєння мхатівських принципів і положень Системи, а особливо враження це справило на молодого Лі Страсберга, вирішивши його подальше творче життя.

Пояснити спрагу до навчання американців у Станіславського можна відсутністю розвитку акторської школи та театральної педагогіки. I, оскільки американський театр проскочив через усі етапи розвитку багатьох форм театру, через які пройшов європейський театр, комерційна організація справи стала його єдиною формою.

Театр Станіславського продемонстрував американському театрові акторську трупу нового рівня: об'єднану спільністю методології, яка говорила єдиною театральною мовою. Саме Художній театр продемонстрував американській публіці й професіоналам театральної справи, що таке акторська школа. Це й стало поштовхом для подальшого розвитку американського театру.

Опора методології Станіславського на об'єктивні закони природи, а не просто на традиції національної акторської школи, робить її універсальною для будь-якої країни. Тому Система стала бажаною і затребуваною в американському театральному процесі.

Важливим наслідком успішних гастролей Художнього театру стало масове виникнення театральних студій «мхатівського кореня», де навчання велося за системою К. С. Станіславського. Серед цих керівників були такі талановиті актори й педагоги: Марія Успенська, Тамара Дейкарханова, Лев і Варвара Булгакови, Михайло Чехов, Віра Солов'йова і Андріус Жилінський, Іван Лазарєв і Марія Астрова, Річард Болевський.

Лі Страсберг - один $з$ перших вихованців Американської Театральної Лабораторії під керівництвом М. Успенської та Р. Болеславського, де Страсберг засвоїв основи системи Станіславського. Саме ці уроки стали методологічною базою усієї його подальшої творчої діяльності. Лабораторія сформувала в режисерові націленість на наслідування об’єктивних законів природи в сфері акторської творчості.
За визначенням А. М. Смелянського, саме Лі Страсберг створив «індустрію Станіславського в Америці», докладаючи зусилля до змістовного розвитку самої системи $[4,26]$.

Починати говорити про Метод Лі Страсберга безперечно треба з аналізу його книги «A Dream of Passion» («Вигадані почуття»), адже саме вона, за задумом самого Страсберга, мала стати першим справжнім описом Методу.

Щоб зрозуміти що $є$ джерелом створення у будь-якому виді мистецтва, Страсберг проаналізував феномен художньої творчості в інших видах мистецтв, взявши у союзники і поетів, і живописців, і філософів, і навіть вчених. Висновок Страсберга — «емоційна пам'ять»,- саме вона є джерелом творчості у його твердженнях. Творчість актора неможлива без вторинних почуттів, без опори на емоційну пам'ять.

Фундаментальним для Страсберга стало твердження, яке прийшло до нього на уроках акторської майстерності у Лабораторному театрі Болеславського від самого Станіславського: «Сутність акторського дару, те, що ми шукаємо для визначення наявності акторської обдарованості,- - це здатність відповідати на уявний подразник» $[8,419]$. У своїй книжці Страсберг називає це емоційною пам'яттю, Станіславський у «Роботі актора над собою»пам'яттю відчуттів, афективною пам'яттю.

Емоційна пам'ять, усебічне розглядання її механізмів, вивчення способів ії активізації і розвитку, а найголовніше, дослідження методів іiі використання у творчості актора - $\epsilon$ наскрізною темою не лише книжки, а й досліджень Страсберга впродовж усього його життя.

Важливою наскрізною темою книжки є педагогічна спадкоємність. Страсберг постійно спирається на досвід світового, а особливо російського, театру. Страсберг сприймає театральну педагогіку як єдиний дієвий процес, що постійно розвивається. Можливо, тому автор спокійно, де лише це можливо, наголошує свою спадкоємність авторові Системи Станіславському, але при цьому спокійно говорить і про свою відмінність. «Майстерність актора,писав Страсберг ще у 1941 році,—-має об'єктивну історію, свій шлях вдосконалення і розвитку. <..> За ті елементи акторської гри, які сьогодні здаються нам як зрозуміле саме по собі, хтось мав боротись, битись, прагнути їх» $[10,102]$. У цьому питанні обидва науковці мислили в одному напрямку, і підтвердженням цьому є слова К. Станіславського: «Ми спостерігаємо у всіх галузях науки, техніки, медицини, як досвід одних стає спадкоємною цінністю наступних поколінь. Тільки у мистецтві та, 
мабуть, у житті люди не бажають приймати досвід близьких людей, котрі полюбовно попереджують про оману та ілюзії...» $[6,381]$.

Говорячи про метод Страсберга, неможливо не говорити про афективну - емоційну пам'ять, адже саме це стало основою, центральним моментом у педагогіці теоретика. Основна критика, яка припадала на Метод, була спрямована саме на цю частину праці Страсберга, але водночас саме це і вважають найвагомішим його вкладом у розвиток театрального мистецтва.

Шлях до справжності переживання, за Страсбергом, лежить через вправу на емоційну пам'ять.

Завдання цієї вправи - воскресити з власної волі певне відчуття, яке актор відчував у житті, і відчути його знову. Наявність розумового або фізичного перенапруження суттєво ускладнює роботу, тому актор до моменту проходження цієї вправи повинен мати достатній навик у релаксації.

Щоб почати вправу, актор обирає емоційний епізод зі свого минулого досвіду і починає згадувати ситуацію зі свого життя хвилин за п'ять до потрібного емоційного моменту.

Правильний процес стимуляції емоційної пам'яті відбувається через згадування відчуттів. Страсберг наголошує: «Актор не може думати взагалі. Двір (який він згадує) складається з багатьох об'єктів, що їх він бачить, чує, відчуває і т.п. Тільки через сенсорну конкретність, тільки через точність відчуттів цих об'єктів можна стимулювати емоції. Недостатньо сказати: «Було спекотно». Актор повинен виявити абсолютно точно, у якій частині тіла він відчував ту саму спеку, яка зараз йому згадалась. Актор локалізує увагу у тій частині, щоб не просто згадати, а щоб повторно прожити - відчути саме той момент. Він згадує, у що був одягнений — вид одягу, тканину, відчуття при іiі контакті з тілом. Актор згадує подію, яка викликала емоцію, не з точки зору послідовності історії, а з точки зору різноманітності відчуттів, які пов'язані з нею» $[10,150]$.

Коли актор детально згадує усі ці подробиці, відбувається одне з двох: або актор виявляє умовний рефлекс, уже сформований природою, або він допомагає природі створити новий умовний рефлекс $\mathrm{i}$ його вмикач. Якщо актор у виконанні вправи зміг знайти і запам'ятати сенсорний пусковий механізм, це означає, що він зміг знайти правильний ключ до певного почуття. Далі проходити увесь цей шлях не знадобиться, досить буде використати цей самий «ключ від почуття».

Отже шлях, запропонований Страсбергом, простий, але принциповий: дорогою відчуттів - до справжнього почуття.
У вихованні актора за Методом Лі Страсберга $є$ класичний порядок вправ, якому викладачі повинні неухильно слідувати. На відміну від Станіславського, який у своїй педагогічній практиці комбінував тренування елементів у найрізноманітніших поєднаннях, Страсберг виявив жорсткий порядок вправ навчання актора. Страсберг багаторазово повторює i наполягає на дотриманні «основних етапів і послідовності підготовки актора, попередньої роботи перед виставою» [10]. Ця послідовність розвивається від простого до більш складних елементів. Але навіть тут, маючи розбіжності у викладанні зі Станіславським, потрібно зауважити, що Страсберг наголошує спадкоємність творцеві Системи: «Усе, 3 чим ми маємо справу у цих вправах,- - релаксація, концентрація, пам'ять фізичних відчуттів, емоційна пам'ять - було визначено Станіславським» $[10,638]$.

Завданням викладача, за Страсбергом, $є$ розвиток здатності контролювати, розділяти і пристосовувати увагу актора. Увага актора, концентрація потрібні Страсбергові не самі по собі. Вони потрібні для створення необхідного рівня віри, при якому актор здатен пережити уявні події і реалії п'єси у всій повноті психологічних реакцій та відгуків.

Отже, розглянемо схему, котру Страсберг надає у своій книжці «Вигадані почуття», за якою і відбувається викладання та опанування Методу.

Ранковий напій (Breakfastdrink). Актор п'є уявну каву, чай — те, що він п’є вранці. Головним ворогом у цій вправі $є$ спроби акторів «імітувати фізичну дію». Тут слід не квапити студента, а, навпаки, заохочувати до зупинок і перевірок. Вже з цієї вправи студентам закладається принцип перевірки, співвідношення вправи $з$ дійсністю.

Перед дзеркалом (Mirror). У цій вправі чоловіки зазвичай голяться, а жінки розчісуються або фарбуються. Вибір дії студент робить самостійно.

Повсякденна дія (Dailyactivity). Ця вправа спрямована на те, щоб актор відчув принципову різницю між м'язовою та сенсорною реальністю. Актора просять виконати просту повсякденну дію, яку він багаторазово робив у житті (зняти туфлі, попрати одяг та ін.). Головне - стимулювати сенсорний відгук. Якщо у актора виникають труднощі, Страсберг пропонує попрацювати зі шматочками трьох різних тканин, і відразу завдання актора стає простішим, адже концентрація спрямована лише на текстуру, а не на весь предмет.

Вправа «Під променями сонця» (Sunshine). Ця вправа не включає в себе задіяння будь-яких м'язів. Завдання актора - уявити та відчути промені сонця на собі, при цьому просто сидячи на стільці у звичайній релаксаційній позі. 3-поміж рухів ак- 
торові дозволяється лише трішки ворушити тією частиною тіла, на якій він відчуває тепло сонця,це допоможе пробудити відповідні частини тіла та водночас зняти напругу з інших його частин.

Вирава «Гострий біль» (Sharp pain). Ця вправа перевіряє інтенсивність пам'яті відчуттів. Тут актор уперше має справу з таким об'єктом уваги, як чуттєва пам'ять. Актор повинен відтворювати відчуття болю у конкретній частині тіла, актор повинен чітко розуміти, в якій частині тіла йому концентрувати увагу. Висхідна реакція на біль має бути інтенсивною, $і$ якщо актор чесно намагатиметься відтворити його, то можна очікувати, що він з'явиться знову, до того ж $з$ тією самою інтенсивністю.

Гострі смакові відчуття (Sharptaste). Продовжується робота над дослідженням інтенсивності пам'яті відчуттів. У цій вправі актор спочатку працює з реальним об'єктом - лимоном, наприклад. Ця домашня робота дає можливість перевірити, наскільки точно працює пам’ять відчуттів.

Pізкий заnax (Sharpsmell). У цій вправі актор перевіряє та тренує свої органи нюху.

Пронизливий звук (Sharpnoise). Ця вправа містить ті ж самі завдання. Продовжуючи виконувати завдання на пам'ять відчуттів, актор по черзі дає завдання кожному зі своїх п'яти органів почуттів.

Спільна робота всіх п'яти органів почуттів (Overallsensation). ВПлив на органи почуттів відбувається не локально, на окремі частини, а на все тіло одразу. (Побути під холодним вітром, дощем, прийняти душ, побувати в сауні). Страсберг акцентує увагу на тому, що різні частини тіла сприймають вплив навколишнього середовища по-різному, особливо акцентує увагу на диханні.

На другому етапі робота актора над концентрацією перетворюється у вправи на багатоплощинну увагу, у яких відбувається поєднання попередніх вправ з одним домінантним об'єктом уваги. Потрібно зауважити, що кожна наступна вправа додається до вправи на спільну роботу усіх органів почуттів.

«Oсобистий предмет» (Personalobject). Саме ця вправа є першою вправою, націленою на отримання емоційного відгуку. Тепер до попередньої вправи вводиться особистий предмет. За термінологією Страсберга предмет стає «особистим», коли актор пов'язує з ним особисту, глибоко хвилюючу подію. Головне завдання викладача простежити, щоб студент не починав спонукати себе до виявлення емоцій, пов'язаних з предметом.

«Звуковий вплив» (Vocalaction). Страсберг завжди наполягав, що з найперших етапів підготовки актора треба готувати його до боротьби зі звичними словесними шаблонами і спрямовувати всі зусилля на те, «щоб актор умів контролювати мимовільні звички і штампи сценічної мови, щоб умів дозволяти словам набувати значення, котре витікає з чуттєвого досвіду чи поведінки» $[10,490]$. У цій вправі зазвичай використовується пісня, яку можна наспівувати без слів. Найчастіше актори прагнуть співати пісню правильно, але завдання вправи полягає не у виконанні правильного ритму або тональності, а у тому, щоб дозволити пісні бути забарвленою тією реальністю, яку створює сам актор, підкорити характер звукової дії негайному самопочуттю актора.

«Повсякденна фізична діяльність». На додаток до спільної роботи п'яти органів почуттів, або особистого предмета, або звукової вправи актор повинен відтворити яку-небудь просту повсякденну фізичну дію - одягатись, розчісуватись, умиватись або готувати сніданок тощо. Це перша вправа, де Страсберг акцентує увагу на послідовному, логічному виконанні дії.

«Монолог». На цьому етапі навчання можна додати монолог (відомий, наприклад, 3 класичної драматургії). «Актор не повинен виконувати монолог з тим смислом, який він мав би у безпосередньому контексті п’єси, навпаки, він дозволяє йому випробувати вплив тих відчуттів, над якими працює актор». Наприклад, монолог може бути виголошений в сауні, у момент сприйняття особистого предмета і одночасно у сонному стані або стані збудження і т.д.

Комбінації запропонованих вище вправ для одночасного виконання можуть бути абсолютно різними - це Страсберг залишає на викладачів. Комбінувати для виконання можна як дві, так і три, і навіть чотири вправи.

Цікаво, що у свої практиці Страсберг завжди просить актора дозволити новому відчуттю виразитись у вже наявній правді відчуттів. Тобто актор ніби має впустити в себе новий імпульс і дозволити органам почуття зробити свою несвідому справу. Страсберг дуже часто використовує дієслово «дозволяй» у своїй практиці.

Наступним етапом у вихованні актора за методом Лі Страсберга стає перевірка на чуйність до зовнішніх вказівок.

«Нова обставина». Коли під час виконання вправ першого або другого рівня актор досягає необхідного самопочуття і здатен підтримувати його певний час, викладач-режисер просить додати нову обставину, наприклад, біль, і пройти через послідовний набір відчуттів ще раз. Актор повинен дозволити словам і усій своїй поведінці адаптуватися до нової обставини. 
«Наодинці із собою» (Privatemoment). Техніка входження у вправу аналогічна попереднім вправам: актор поступово відтворює чуттєві подробиці місця, оточення, в яких відбувається його існування «наодинці». Далі він додає умови, які мотивують його поведінку і т.д. Сама вправа триває близько години, і її неперервність дає змогу сподіватися, що у майбутній професійній діяльності актор буде здатен підтримувати самопочуття, яке здобув у вправі, досить тривалий час, і цього вистачатиме на акт п’єси.

Bnрава «Tварини» (Animalexercise). Головне в цій вправі, за Страсбергом, те, що вона допомагає акторові усвідомити різницю між собою і персонажем. Для акторів Методу, у послідовності тренінгу — це перша вправа, яка піднімає питання і веде до фізичної характерності, тобто перша вправа 3 класу спостерігання. Особливість вправи полягає в тому, що спочатку вона не потребує концентрації внутрішньої уваги на собі, актор спостерігає за твариною, перебирає на себе іiі характерні особливості, пластику. Потім актор починає імітувати повадки тварини. Далі він перевіряє відчуття фізичного почуття тварини - сонливість кота, цікавість мавпочки і т.д. Засвоївши сенсорну складову фізичної поведінки тварини, використовуючи іiі звуки, актор «піднімає» свою тварину на ноги, продовжуючи підтримувати властивий цій тварині баланс енергії. Це процес продовжується до того часу, поки у актора не вийде людина 3 характерністю тварини. Тим самим вправа підводить до освоєння характеру персонажа [8].

Вирава на емоційну пам'ять. (Emotional-memory exercise). Завдання цієї вправи полягає в тому, щоб свідомо, зусиллям волі, згадати в повному сенсорному обсязі відчуття, які супроводжували ситуацію, і тоді механізм емоційної пам'яті несвідомо оживить давні емоції, відтворить їх сьогодні. Дуже важливий момент - Страсберг пропонує досліджувати чуттєвий досвід, який відбувся не менше ніж сім років тому, і застерігає від вибору нещодавньої події-чим раніше відбувся досвід, тим краще.

Вирава "Співаємо-танцюемо» (Song-anddance exercise). Вправа починається з підготовчого етапу. Спочатку викладач просить вийти актора на сцену і просто стояти, дивлячись на людей у репетиційній залі. Виявляється, просто стояти на сцені не таке вже й просте завдання. Потрібно усвідомити енергію свого тіла, знайти його центр і просто стояти будучи самим собою. На другому етапі вправи акторові пропонується обрати собі простеньку пісеньку і заспівати ії не так як зазвичай, а максимально розділяючи та протягуючи кожен склад, даючи кожній голосній найповніший звук. При цьому треба намагатися зберегти мелодію [10].

Наступним етапом вправи стає танець, але він також іде врозріз з патернами поведінки. Актора знову просять стати вільно, а потім - несподівано скомандувати собі зробити якийсь непідготовлений рух, не задумуючись. Актор не повинен знати, що саме він зараз зробить. Просто скомандувати собіворухнись! I хоч що б вийшло — чудово [8].

Педагог просить повторити актора низку рухів, які він щойно виконав, потім ще раз, і ще раз. Час, за який актор повторює рухи, створює певний ритм. Далі актор має чітко повторювати і рух, і його ритм, адже виконавець повинен вміти бути і спонтанним, і чітко повторювати те, що мимовільно народилось у ході репетицій. До вже налагодженого «танцю», наступним етапом стає додавання пісні, тільки тепер склади співаються вибухово і різко. Це допоможе звільнити голос від непотрібної напруги. Але потрібно, щоб танець і пісня виконувалися врозріз. Танець іде сам по собі, а пісня сама по собі, їх ритми не повинні збігатися.

На цій вправі Страсберг підводить риску під етапом навчання, який повністю спрямований на «роботу актора над собою».

Виходячи з проведеного дослідження та проаналізувавши літературну спадщину Лі Страсберга можна зробити певні висновки про співвідношення Системи і Методу. Обидві театральні школи спрямовані на підготовку акторів, які можуть працювати у будь-якій естетичній системі, у будь-якому жанрі. Обидва носії актороцентричного театророзуміння стверджують, що правда акторської гри - це правда життєвого досвіду, поведінки і виразності. Відмінною рисою у викладанні Методу є сувора послідовність та поетапність «тренінгу і муштри», чого не надає К. Станіславський. Педагогічні підходи Страсберга відрізняються уїдливістю і вимогливістю. Метод акцентує увагу на ретельній попередній підготовці актора і його вихованні до початку роботи над драматургією. Слід зауважити, що методи акторської майстерності, запропоновані у XX столітті, були створені режисерами і акторами, а Метод Лі Страсберга був створений педагогом. Метод Лі Страсберга як сучасна школа підготовки актора $€$ методологічно вивіреним, науково обгрунтованим, практично дослідженим та ефективним.

\section{Джерела та література}

1. Кристи Г. В. Книга К. С. Станиславского «Работа актера над собой» / К. С. Станиславский. Собр. соч.: В 8 т. Москва, 1954. Т. 2. С. $5,13$.

2. Кристи Г. В. Примечания / К. С. Станиславский. Собр. соч.: В 8 т. Т. 3. С. 488. 
3. Рибо Т. Психология чувств; пер. М. Гольдсмит. Санкт-Петербург, 1898. С. 153.

4. Смелянский А. М. Профессия - артист / К. С. Станиславский. Собр. соч.: В 9 т. Т. 2. Москва, 2007. С. 26.

5. Станиславский К. С. «Работа актера над собой» / К. С. Станиславский. Собр. соч.: В 8 т. Москва, 1955. С. 98.

6. Станиславский К. С. Собрание сочинений: В 9 т. Т. 2. Москва, 2007. С. 376, 377-378, 381, 407.

7. Черкасский С. Д. Станиславский и йога // Bonpocb meaтра. Санкт-Петербург, 2013.

8. Mekler, E. The New generation of Acting Teachers. New York: Penguin, 1987. P. 412.

9. Smith, W. Real Life Drama. Boston, 1990. P. 21, 31, 72, 77, 66.

10. Strasberg, L. A Dream of Passion: The Development of the Method. Boston: Little, Brown, 1987. P. 36-37, 40, 102.

\section{References}

1. Kristi, G. V. (1954). Book by K. S. Stanislavskyi «Actor's self-improvement»/ K. S. Stanislavskiy. Sobr. soch.: V 8 t. Moscow. T. 2. S. 5, 13 [in Russian].
2. Kristi, G. V. Notes / K. S. Stanislavskiy. Sobr. soch.: V 8 t. T. 3. S, 488 [in Russian].

3. Ribo, T. (1898). Psychology of feelings; per. M. Goldsmit. Sankt-Peterburg. S. 153 [in Russian].

4. Smelyanskiy, A. M. (2007). A profession is an artist/ K. S. Stanislavskiy. Sobr. soch.: V 9 t. T. 2. Moscow. S. 26 [in Russian].

5. Stanislavskiy, K. S. (1955). «Actor's self-improvement»/ K. S. Stanislavskiy. Sobr. soch.: V 8 t. Mosco, 1955. S, 98 [in Russian].

6. Stanislavskiy, K. S. (2007). Sobranie sochineniy: V 9 t. T. 2. Moscow. S. 376, 377-378, 381, 407 [in Russian].

7. Cherkasskiy, S. D. (2012). Stanislavskyi and yoga // Voprosyi teatra. Sankt-Peterburg [in Russian].

8. Mekler, E. (1987). The New generation of Acting Teachers. New York: Penguin. P. 412 [in English].

9. Smith, W. (1990). Real Life Drama. Boston. P. 21, 31, 72, 77, 66 [in English].

10. Strasberg, L. (1987). A Dream of Passion: The Development of the Method. Boston: Little, Brown. P. 36-37, 40, 102. [in English]. 